\title{
Tanggapan Siswa Dan Guru Terhadap Pornografi dan Perilaku Pelecehan Seksual Siswa pada SMP Negeri 3 Soe
}

\section{Research and Students 'Response to Pornography and Sexual Student Behavior Health In State High School 3 Soe}

\author{
Maglon Ferdinand Banamtuan a,1 \\ a Program Studi Pendidikan IPS, Program Pascasarjana, Universitas Nusa Cendana Kupang \\ e-mail: ${ }^{1}$ Machonope@gmail.com
}

\begin{tabular}{ll}
\hline Informasi artikel & ABSTRAK \\
\hline Kata Kunci: & Tujuan penelitian ini adalah untuk mengetahui pendapat atau tanggapan \\
tanggapan siswa dan & dari guru dan siswa terhadap pornografi dan perilaku pelecehan seksual \\
guru, pornografi, & siswa. \\
pelecehan seksual & Metode yang dipakai dalam penelitian ini adalah teknik analisis
\end{tabular}
Metode yang dipakai dalam penelitian ini adalah teknik analisis deskripsi kualitatif yaitu menggambarkan dengan kata-kata atau kalimat dalam bentuk tulisan kemudian penulis mengambil suatu kesimpulan.

Hasil penelitian adalah Hasil penelitian adalah: 1). Pornografi tidak baik dan dapat memberi pengaruh buruk terhadap anak-anak khususnya usia sekolah dalam membentuk kepribadian mereka, sehingga pornografi atau sejenisnya tidak baik bagi anak-anak tersebut; 2). Akan diberi sanksi khusus dari pihak sekolah yaitu dengan cara memanggil orang tua atau siswa tersebut diberi teguran keras berupa skorsing; 3). mental anak tersebut terpengaruh, karena rasa ingin tahu yang tinggi sehingga anak tersebut ingin melakukan apa yang dilihat; 4). Melanggar hukum dan kode etik yang ada karena seperti yang kita ketahui bersama budaya orang timor yang menjunjung nilai kesopanan di rusak dengan adanya tindak pelecehan seksual dan hal-hal yang mengandung pornografi; 5). Apabila mendapati HP siswa yang terdapat video atau gambar porno maka akan di tindaklanjuti serta dari pihak sekolah akan memberikan pelayanan konseling bagi siswa tersebut; 6). siswa di beri sanksi tegas dari pihak sekolah dan selanjutnya diberikan kepada pihak yang berwajib karena tindakan seperti itu sudah melanggar hukum; dan 7). Terpengaruh karena menonton atau melihat hal yang mengandung pornografi sehingga anak tersebut terdorong untuk melakukan hal tersebut.

Keywords:

student and teacher responses, pornography, sexual harassment

\section{ABSTRACT}

The purpose of this study was to find out opinions or responses from teachers and students on pornography and student sexual abuse behavior.

The method used in this study is a qualitative description analysis technique that is to describe the words or sentences in the form of writing and then the authors take a conclusion.

The result of this research are: 1). Pornography is not good and can adversely affect children especially school age in shaping their personality, so pornography or the like is not good for the children; 2). Will be given a special sanction from the school that is by calling the parents or students are given a hard rebuke of a suspension; 3). The 
child's mental being affected, out of curiosity so high that the child wants to do what he sees; 4). Violate existing laws and codes of ethics because as we know with the culture of the timor people who uphold the value of modesty is ruined by sexual harassment and pornography; 5). If you find HP students who have video or pornographic images it will be followed up and from the school will provide counseling services for these students; 6). Students are given strict punishment from the school side and subsequently given to the authorities because such acts have violated the law; And 7). Be influenced by watching or seeing things that contain pornography so that the child is compelled to do so.

\section{PENDAHULUAN}

Kata pornografi dalam Kamus Besar Bahasa Indonesia disebutkan Pornografi adalah penggambaran tingkah laku secara erotis dengan lukisan atau tulisan untuk membangkitkan nafsu birahi. Dengan sendirinya tulisan yang memakai kata-kata yang bersangkutan dengan seksualitas dan memakai gambar-gambar yang memunculkan alat kelamin atau hubungan kelamin adalah pornografi, sedangkan Haung menyebutkan pornografi adalah penggunaan refresentasi perempuan (tulisan, gambar, foto, video dan film) dalam rangka manipulasi hasrat (desire) orang yang melihat, yang di dalamnya berlangsung proses degradasi perempuan dalam statusnya sebagai “objek" seksual laki-laki.

Pornografi umumnya dikaitkan dengan tulisan dan penggambaran, karena cara seperti itulah yang paling banyak ditemukan dalam mengekspos masalah seksualitas. Materi seksualitas yang dibuat oleh manusia dalam bentuk gambar, sketsa, ilustrasi, foto, tulisan, suara, bunyi, gambar bergerak, animasi, kartun, syair, percakapan, gerak tubuh atau bentuk pesan komunikasi lain, melakukan berbagai bentuk media komunikasi dan/atau pertunjukan di muka umum yang dapat membangkitkan hasrat seksualitas dan/atau melanggar nilai-nilai kesusilaan dalam masyarakat.

Akhir-akhir ini dalam masyarakat kita ada istilah baru yaitu porno aksi. Yang dimaksudkan kiranya adalah penampilan seseorang yang sedikit banyak menonjolkan hal-hal seksual, misalnya gerakan-gerakan yang merangsang atau cara berpakaian minim yang menyingkap sedikit atau banyak bagian-bagian yang terkait dengan alat kelamin, misalnya bagian dari paha. Terjadinya krisis yang mengkhawatirkan dalam masyarakat saat ini yang melibatkan orang-orang yang paling berharga yaitu anak-anak. Satu sisi kemajuan zaman ini memberikan banyak kemajuan teknologi yang memungkinkan anak memperoleh fasilitas yang serba canggih. Anak-anak sekarang sejak dini sudah mengenal HP, kamera, internet dan lain-lain. Namun di 
sisi lain kemajuan tersebut juga membawa dampak negatif seperti tersedianya informasi negatif yang sulit untuk dihindari, misalnya kekerasan, pornografi, konsumerisme melalui berbagai media informasi tersebut. Dampak buruk perkembangan media masa dan teknologi sekarang ini ternyata bukan hanya terjadi pada kalangan remaja, tetapi sudah menyentuh anak-anak sekolah dasar. Anakanak sekarang bisa dengan bebas dan leluasa menerima informasi, baik yang positif maupun yang negatif. Dengan tingginya rasa ingin tahu yang memang merupakan ciri khas anak, di tambah dengan banyaknya rangsangan dari luar membuat anak sangat penasaran dengan perubahan dan gejolak yang sedang terjadi pada dirinya.

Terdapat banyak bahaya yang ditimbulkan oleh pornografi, yang sifatnya secara berangsur-angsur dan bisa menyebabkan kecanduan. Orang yang gemar minuman keras, lama-lama dia akan menjadi pecandu. Anak-anak juga demikian, semakin sering melihat hal-hal berbau pornografi, kemungkinan terjadi penyimpangan seksual atau kecanduan seks semakin besar. Apa lagi saat ini media elektronik dan massa, semakin gencar menayangkannya. Kondisi semacam ini akan memperbesar bahaya potensial yang ada pada pornografi. Perubahan trend pola hidup dan menjalani hidup akan memberikan dampak yang positif dan negatif pada remaja, dengan tidak memandang apakah di kota atau di Desa.

Remaja pada masa seksual akktif akan berusaha mencari cara untuk memenuhi kebutuhan seksualnya. Berbagai cara dapat mereka lakukan apakah dengan berpacaran tanpa komitmen, persahabatan tanpa passion atau suka tanpa passion dan komitmen. Dan kebanyakan remaja yang tidak menjalani hubungan dengan pasangan (pacaran), mencoba masturbasi, onani, menonton film porno, mengkoleksi gambar-gambar porno atau melakukan pelecehan seksual. Hal ini menjadi bukti secara implicit bahwa masih banyak yang menikmati pornografi sebagai sebuah sensasi atau seni.

Anak-anak sering meniru apa yang dibaca, dilihat atau yang didengar. Banyak penelitian mengemukakan bahwa pornografi dapat mendorong mereka melakukan tindakan seksual terhadap anak yang lebih muda, kecil dan lemah. Para ahli di bidang kesehatan seksual terhadap anak menyatakan bahwa aktifitas seksual pada anak yang belum dewasa selalu memunculkan dua (2) kemungkinan pemicu : pengalaman dan melihat. Hal ini berarti bahwa anak-anak yang menyimpang secara seksual mungkin telah tercemar atau 
gampang melihat hal-hal seksual melalui pornografi.

Pelecehan seksual adalah segala macam bentuk perilaku yang berkonotasi seksual dan tidak senonoh yang dilakukan secara sepihak dan tidak diharapkan oleh orang yang menjadi sasaran sehingga menimbulkan reaksi negatif: rasa malu, marah, dan tersinggung pada diri korban. Berdasarkan pengertian di atas tingkat pelecehan seksual dapat dibagi dalam tiga tingkatan. Pertama, tingkatan ringan, seperti godaan nakal, ajakan iseng, dan humor porno. Kedua, tingkatan sedang, seperti memegang, menyentuh, meraba bagian tubuh tertentu, hingga ajakan serius untuk "berkencan". Ketiga, tingkatan berat, seperti perbuatan terang-terangan dan memaksa, penjamahan, pemaksaan kehendak, hingga percobaan pemerkosaan. Sedang pemerkosaan itu sendiri sudah masuk dalam kategori kejahatan seksual (sexual crime).

Kasus pelecehan seksual tak pandang usia, jenis kelamin, ras, tingkat pendidikan, latar belakang sosial dan agama. Pelecehan seksual mulai dari yang ringan hingga berat sangat mungkin menimpa kita dan keluarga kita tanpa kita sadari. Pelecehan seksual bahkan juga bisa terjadi di tempat yang dianggap kental nilai moralnya, seperti di lingkungan sekolah dan yang lainnya. Pergaulan mereka yang luas, otomatis mereka juga memperoleh banyak masukan dari teman-temannya. Perkembangan moral anak yang sesungguhnya dapat dilihat dari dua (2) aspek yaitu perilaku moral dan pertimbangan moral.

Perilaku moral adalah perilaku yanh dilandasi atau dipikirkan sebelumnya oleh pelakunya, berupa alasan dan motivasi yang bernilai moral (Kurtines \& Gerwitz, 1992). Sebaliknya sesuatu tindakan tidak dapat dipandang sebagai perilaku moral, bila perilaku tersebut tidak pernah dipikirkan oleh pelakunya, misalnya seorang yang melompat ke sungai untuk menyelamatkan orang lain yang hendak tenggelam, akan tetapi motivasinya adalah untuk mendapatkan hadiah, maka tindakan tersebut tidak dapat di pandang sebagai sebuah perilaku bermoral. Dengan kata lain, betapapun bermanfaatnya suatu perilaku moral terhadap nilai kemanusiaan, namun jika perilaku tersebut tidak disertai dan didasarkan pada pertimbangan moral, maka perilaku tersebut belum dapat dikatakan sebagai perilaku moral yang mengandung nilai moral.

Sementara pertimbangan moral menurut Kohlberg (1995) merupakan apa yang diketahui dan dipikirkan seseorang mengenai baik dan buruk atau besar dan salah. Pertimbangan moral bukan berkenaan dengan jawaban atas pertanyaan 
"apa yang baik dan buruk" melainkan terkait dengan jawaban atas pertanyaan mengapa dan bagaimana seseorang sampai pada keputusan bahwa sesuatu dianggap baik dan buruk. Berdasarkan latar belakang maka penulis berpendapat bahwa keterlibatan salah seorang siswa SMP N 3 dalam sebuah tindakan yaitu memegang payudara dari seorang siswi itu termasuk dalam sebuah pelecehan seksual kasus ini terjadi pada tahun 2008. Ada juga keterlibatan seorang siswa SMP N 3 yaitu terlibat dalam pemerkosaan yang terjadi pada seorang gadis remaja. Pemerkosaan itu dilakukan oleh tujuh (7) orang pelaku, dan setelah ditelusuri kasus ini maka didapati seorang siswa SMP N 3 yang ikut terlibat didalam kasus pemerkosaan itu, kasus ini terjadi pada tahun 2010. Berdasarkan dua kasus diatas maka penulis berpendapat bahwa pornografi sangat berpengaruh besar pada moral dan perilaku anak.

Berdasarkan uraian di atas maka dapat dirumuskan sebuah rumusan permasalahan tentang: 1). Bagaimanan tanggapan guru terhadap pornografi dan perilaku pelecehan seksual siswa di SMP Negeri 3 Soe?; dan 2). Bagaimanan tanggapan siswa terhadap pornografi dan perilaku pelecehan seksual siswa di SMP Negeri 3 Soe?.
Penelitian ini dilakukan di SMP Negeri 3 Soe, Kecamatan Kota Soe, Kabupaten Timor Tengah Selatan, yang menjadi objek dalam penelitian ini adalah siswa kelas Sembilan (IX) dan guru di SMP Negeri 3 Kecamatan Kota Soe, Kabupaten Timor Tengah Selatan sebanyak 25 orang yang di ambil secara acak. Metode yang dipakai dalam penelitian ini adalah teknik analisis deskripsi kualitatif yaitu menggambarkan dengan kata-kata atau kalimat dalam bentuk tulisan kemudian penulis mengambil suatu kesimpulan. Sedangkan teknik yang digunakan dalam penelitian ini yaitu: 1). Angket kepada siswa; 2). Wawancara kepada guru; dan 3). Dokumentasi.

\section{HASIL DAN PEMBAHASAN}

Berdasarkan penelitian yang dilakukan oleh penulis, maka penulis akan memaparkan data hasil penelitian sebagai berikut :

\section{Tanggapan siswa dan guru terhadap pornografi}

Tanggapan adalah pendapat dan pemahaman seseorang sebagai buah pemikiran yang diungkapkan dalam bentuk pernyataan verbalistis terhadap suatu fenomena atau masalah yang sedang dihadapi atau dialami.

\section{METODE}


Pertanyaan: Bagaimana

tanggapan anda, apakah

pornografi dapat

mempengaruhi perilaku siswa?

Jawaban: Ya. Karena seperti yang kita ketahui bersama bahwa pornografi tidak baik dan dapat memberi pengaruh buruk terhadap anak-anak khususnya usia sekolah dalam membentuk kepribadian mereka, sehingga pornografi atau sejenisnya tidak baik bagi anak-anak tersebut.

Dari tanggapan siswa di atas menunjukkan bahwa hal pornografi tidak baik dan dapat memberi pengaruh buruk terhadap anak-anak khususnya anak usia sekolah dalam membentuk kepribadian mereka, sehingga pornografi atau sejenisnya tidak baik bgi anak-anak.

Dengan demikian penulis menganalisis bahwa pornografi benarbernar dapat berpengaruh buruk pada anakanak terutama anak usia sekolah. Pengaruh buruk yang akan dialami yaitu dalam membentuk kepribadian anak.

Pertanyaan: Bagaimana pihak sekolah menyikapi perilaku siswanya yang mengandung unsur pornografi atau pelecehan seks?
Jawaban: Mereka akan diberi sanksi khusus dari pihak sekolah yaitu dengan cara memanggil orang tua atau siswa tersebut diberi teguran keras berupa skorsing.

Dari tanggapan di atas maka dapat menunjukan bahwa 25 responden (100\%) yang menjawab bahwa akan memberikan sanksi kusus dari pihak sekolah kepada anak apabila mendapati anak yang berperilaku tidak senonoh atau pantas yang mengandung unsur pelecehan seksual atau percabulan terhadap sesam, yaitu sanksi yang akan diberikan adalah memanggil orang tua atau sekolah memberikan skorsing.

Dengan demikian penulis menganalisis bahwa sekolah akan mengambil tindakan berupa sanksi terhadap siswa yang kedapatan berperilaku yang mengandung unsur pelecehan seksual atau percabulan terhadap sesama. Sanksi berupa panggilan terhadap orang tua atau anak di berikan skorsing oleh pihak sekolah.

Pertanyaan: Bagaimana pendapat anda apakah dengan melihat gambar atau menonton video yang mengandung unsur pornografi siswa akan terpengaruh untuk melakukan 
apa yang telah dilihat atau di tontonnya?

Jawaban: Ya. Karena secara mental anak tersebut terpengaruh, karena rasa ingin tahu yang tinggi sehingga anak tersebut ingin melakukan apa yang dilihat.

Dari tanggapan di atas maka dapat menunjukan bahwa 25 responden $(100 \%)$ yang menjawab bahwa secara mental anak usia sekolah akan terpengaruh, karena rasa keingintahuan anak yang sangat tinggi sehingga anak tersebut ingin melakukan atau mencontohi apa yang telah dilihatnya.

Dengan demikian penulis menganalisis bahwa mental anak akan terpengaruh terhadap hal yang mengandung unsur pornografi, karena dalam masa pertumbuhan anak usia sekolah rasa keingintahuannya sangat tinggi. Sehingga apa yang telah dilihat atau ditontonnya, dia ingin mencontohi atau melakukan seperti yang dilihatnya.

Pertanyaan: apa itu Konsep dari pornografi dan perilaku pelecehan seksual?

Jawaban: Pornografi adalah mengumbar aurat, melukiskan atau menceritakan hubungan intim dan juga dapat membangkitkan gairah seksual misalnya porno aksi dan pornografi. Pornografi adalah memperlihatkan atau menunjukan bagian Perilaku pelecehan seksual adalah bentuk perbuatan seksualitas yang menyimpang dari normanorma etis yang berlaku. Bentuk penyimpangan diantaranya pemerkosaan dan pelecehan seksual.

Dari tanggapan di atas dapat menunjukan bahwa 25 responden (100\%) yang menjawab mereka menyetujui bahwa pornografi adalah gambaran atau cerita yang memperlihatkan hubungan intim melalui video ataupun gambar. Ada juga yang termasuk dalam kategori porno aksi yaitu tindakan berupa mengumbar aurat atau gerakan-gerakan yang dilakukan oleh seseorang yang tidak senonoh atau tidak pantas untuk di perlihatkan. Sedangkan perilaku pelecehan seksual merupakan bentuk perbuatan atau tindakan seksualitaas yang telah menyimpang dari nilai-nilai dan norma-norma yang ada. Bentuk penyimpangan tersebut diantaranya pemerkosaan dan pelecehan seksual.

Dengan demikian penulis menganalisis bahwa pornografi dan porno aksi tidak layak atau tidak pantas dilakukan, sedangkan pelecehan seksual merupakan 
tindakan yang telah melanggar norma dan nilai yang berlaku di masyarakat.

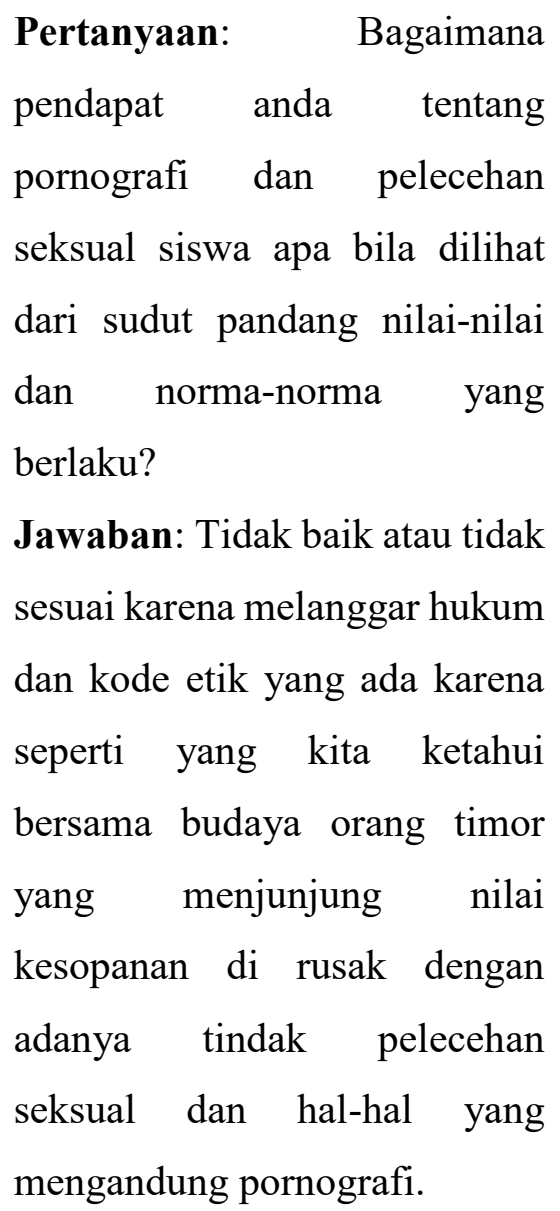

Dari tanggapan di atas menunjukan bahwa 25 responden $(100 \%)$ mengatakan bahwa pornografi dan tindakan pelecehan seksual tidak baik atau tidak sesuai dengan kerena sudah melanggar hukum atau kode etika suatu wilayah atau tempat yang menjunjung tinggi nilai-nilai kesopanan.

Dengan demikian penulis menganalisis bahwa hal yang mengenai dengan pornografi dan pelecehan seksual tidak sesuai dengan aturan hukum dank ode etik dari suatu tempat atau wilayah yang sangat menjunjung tinggi nilai-nilai kesopanan dan norma yang berlaku di masyarakat.

\section{Pornografi}

Pornografi adalah mengumbar aurat, melukiskan atau menceritakan hubungan intim dan juga dapat membangkitkan gairah seksual misalnya porno aksi dan pornografi.

Pertanyaan: Apakah anda sering melakukan rasia terhadap HP siswa dan mendapati adanya video porno dan gambar porno?

Jawaban: Ya. apa bila mendapati HP siswa yang terdapat video atau gambar porno maka akan di tindaklanjuti serta dari pihak sekolah akan memberikan pelayanan konseling bagi siswa tersebut.

Dari tanggapan di atas dapat menunjukan bahwa 25 responden (100\%) menyatakan bahwa pihak sekolah sering melakukan rasia terhadap HP dari pada siswa agar mencegah adanya video dan gambar atau sejenisnya yang mengandung unsur pornografi, dan apa bila mendapati hal-hal tersebut maka siswa yang bersangkutan akan di beri sanksi dan bimbingan konseling.

Dengan demikian penulis menganalisis bahwa sekolah berupaya 
mencegah hal-hal yang mengandung unsur pornografi dan sejenisnya dengan berbagai upaya dan aturan tatatertib yang di berlakukan kepada siswa.

\section{Aspek perilaku pelecehan seksual}

Deviasi perilaku seksual adalah bentuk perbuatan seksualitas yang menyimpang dari norma-norma etis yang berlaku. Bentuk penyimpamgan diantaranya pemerkosaan dan pelecehan seksual.

Pertanyaan: Apakah anda
pernah melihat penyimpangan
perilaku seksual atau
pencabulan yang dilakukan
siswa terhadap sesama?
Jawaban: Ya. Tindak lanjut
dari masalah itu yaitu siswa di
beri sanksi tegas dari pihak
sekolah dan selanjutnya
diberikan kepada pihak yang
berwajib karena tindakan
seperti itu sudah melanggar
hukum.

Dari tanggapan di atas dapat menunjukan bahwa 25 responden (100\%) menyatakan bahwa pernah terjadi pelecehan seksual atau percabulan yang dilakukan oleh siswa terhadap sesamanya dan pihak sekolah memberikan sanksi tagas kepada siswa yang melakukan pelecehan seksual, dan selanjutnya diberikan kepada pihak yang berwajib karena tindakan seperti itu sudah melanggar hukum.

Dengan demikian penulis menganalisis bahwa tindakan pelecehan seksual pernah dan sudah dilakakukan oleh anak usia sekolah yang dilakukan terhadap anak seusianya, dan sekolah memberi sanksi yang tegas terhadap siswa yang melakukan hal tersebut.

\section{Pertanyaan: Bagaimana} pendapat anda jika siswa yang sering mengucapkan kata-kata yang mengandung unsur pornografi dapat berpengaruh negatif pada sikap dan tingkahlaku siswa?

Jawaban: Ya. Karena dengan mengucapkan kata-kata itu dengan sendirinya membuat karakter anak tidak baik atau tidak sopan.

Dari tanggapan di atas dapat menunjukan bahwa 25 responden (100\%) menyatakan bahwa kata-kata yang mengandung unsur pornografi dapat berpengaruh yang negatif terhadap karakter atau kepribadian yang anak usia sekolah yaitu karakter dan kepribadian yang tidak sopan santun dalam berkomunikasi.

Dengan demikian penulis menganalisis bahwa kata-kata yang mengandung unsur pornografi juga dapat 
mempengaruhi karakter anak tidak baik atau tidak sopan dalam berkomunikasi dengan sesamanya maupun dengan pihak lainnya.

\section{Pertanyaan: Bagaimana}

pendapat anda apakah perilaku pelecehan seksual siswa terjadi secara spontan atau karena pengaruh menonton hal yang mengandung unsur pornografi?

Jawaban: Ya. Terpengaruh karena menonton atau melihat hal yang mengandung pornografi sehingga anak tersebut terdorong untuk melakukan hal tersebut.

Dari tanggapan di atas dapat menunjukan bahwa 25 responden (100\%) menyatakan bahwa anak usia sekolah sering kali menirukan apa yang dilihat dan ditontonnya dalam kesehariannya. Begitu pula dengan tindakan pelecehan seksual yang dilakukan oleh anak usia sekolah, karena dia pernah melihat atau menonton hal yang mengandung unsur atau sejenisnya maka hal itu akan selalu terbayang dan selalu dipikirkannya untuk melakukan seperti apa yang telah dia lihat.

Tanggapan adalah pendapat dan pemahaman seseorang sebagai buah pemikiran yang diungkapkan dalam bentuk pernyataan verbalistis terhadap suatu fenomena atau masalah yang sedang dihadapi atau dialami.

Pornografi adalah penggambaran tingkah laku secara erotis dengan lukisan atau tulisan untuk membangkitkan nafsu birahi. Dengan sendirinya tulisan yang memakai kata-kata yang bersangkutan dengan seksualitas dan memakai gambargambar yang memunculkan alat kelamin atau hubungan kelamin adalah pornografi. Pornografi umumnya dikaitkan dengan tulisan dan penggambaran, karena cara seperti itulah yang paling banyak ditemukan dalam mengekspos masalah seksualitas. Materi seksualitas yang dibuat oleh manusia dalam bentuk gambar, sketsa, ilustrasi, foto, tulisan, suara, bunyi, gambar bergerak, animasi, kartun, syair, percakapan, gerak tubuh atau bentuk pesan komunikasi lain, melakukan berbagai bentuk media komunikasi dan/atau pertunjukan di muka umum yang dapat membangkitkan hasrat seksualitas dan/atau melanggar nilai-nilai kesusilaan dalam masyarakat.

Deviasi perilaku seksual adalah bentuk perbuatan seksualitas yang menyimpang dari norma-norma etis yang berlaku. Bentuk penyimpamgan diantaranya pemerkosaan dan pelecehan seksual. segala macam bentuk perilaku yang berkonotasi seksual dan tidak senonoh yang dilakukan secara sepihak dan tidak 
diharapkan oleh orang yang menjadi sasaran sehingga menimbulkan reaksi negatif : rasa malu, marah, dan tersinggung pada diri korban. Pelecehan seksual tak pandang usia, jenis kelamin, ras, tingkat pendidikan, latar belakang sosial dan agama. Pelecehan seksual mulai dari yang ringan hingga berat sangat mungkin menimpa kita dan keluarga kita tanpa kita sadari. Pelecehan seksual bahkan juga bisa terjadi di tempat yang dianggap kental nilai moralnya, seperti di lingkungan sekolah dan yang lainnya. Pergaulan mereka yang luas, otomatis mereka juga memperoleh banyak masukan dari teman-temannya. Rangsangan kuat dari luar seperti film-film seks (blue film), sinetron, buku-buku bacaan dan majalah-majalah bergambar seksi, godaan dan rangsangan dari kaum pria, serta pengamatan secara langsung terhadap perbuatan seksual tidak hanya mengakibatkan memuncaknya atau semakin panasnya reaksi-reaksi seksual tetapi juga mengakibatkan kematangan seksual yang lebih cepat pada diri anak.

Adapun hasil temuan yang peneliti peroleh adalah bahwa Pornografi dapat mendorong anak melakukan tindakan pelecehan seksual terhadap anak lain. Anak-anak sering meniru apa yang dibaca, dilihat atau yang didengar.

Rangsangan kuat dari luar seperti film-film porno, sinetron, buku-buku bacaan dan majalah-majalah bergambar seksi dan porno, serta pengamatan secara langsung terhadap perbuatan seksual tidak hanya mengakibatkan memuncaknya atau semakin panasnya reaksi-reaksi seksual tetapi juga mengakibatkan kematangan seksual yang lebih cepat pada diri anak. Luasnya informasi tentang seksual ini dan mudah diperolehnya informasi tersebut, harus diimbangi dengan berpikir dan berperilaku positif dari para anak agar mereka tidak salah mengartikan tentang seksualitas.

Aktifitas pelecehan seksual pada anak yang belum dewasa selalu memunculkan dua kemungkinan pemicu: pengalaman dan melihat. Hal ini berarti bahwa anak-anak yang menyimpang secara seksual mungkin telah tercemar atau gampang melihat hal-hal seksual melalui pornografi. Anak mudah meniru dan melakukan apa yang pernah dan telah dilihatnya baik itu secara langsung maupun melalui media lainnya. Karena anak usia sekolah memiliki rasa keingintahuan dengan apa yang mereka lihat dan ingin membuat seperti yang dilihat mereka.

\section{SIMPULAN}

Pornografi membelokkan proses perkembangan kepribadian normal, dengan memberikan informasi yang salah tentang seksualitas, perasaan terhadap diri dan 
jasmani yang membuat anak binggung, berubah dan rusak. Pronografi sering mengenalkan pada sensasi seksual sebelum waktunya. Padahal secara perkembangan, anak-anak belumlah siap menghadapinya. Pengetahuan tentang sensasi seksual ini dapat membingungkan dan memberi rangsangan berlebihan pada anak. Rangsangan seksual pornografi dan akibat akhir yang diperoleh darinya adalah merusak jiwa.

Pornografi dapat mendorong anak untuk melakukan tindakan seksual terhadap anak yang lebih muda, kecil dan lemah. Aktifitas seksual pada anak yang belum dewasa selalu memunculkan dua kemungkinan pemicu : pengalaman dan melihat. Hal ini berarti bahwa anak-anak yang menyimpang secara seksual mungkin telah tercemar atau gampang melihat halhal seksual melalui pornografi.

Pelecehan seksual adalah segala macam bentuk perilaku yang berkonotasi seksual dan tidak senonoh yang dilakukan secara sepihak dan tidak diharapkan oleh orang yang menjadi sasaran sehingga menimbulkan reaksi negatif : rasa malu, marah, dan tersinggung pada diri korban. Pelecehan seksual tak pandang usia, jenis kelamin, ras, tingkat pendidikan, latar belakang sosial dan agama. Pelecehan seksual mulai dari yang ringan hingga berat sangat mungkin menimpa kita dan keluarga kita tanpa kita sadari.

Dari rangkaian pembahasan di atas, maka penulis dapat menarik kesimpulan sebagai berikut:

1. Tanggapan siswa tentang pornografi dan perilaku pelecehan seksual

a. Pornografi umumnya dikaitkan dengan tulisan dan penggambaran, karena cara seperti itulah yang paling banyak ditemukan dalam menunjukan masalah seksualitas.

b. Semakin sering melihat hal-hal yang mengandung pornografi, kemungkinan terjadi penyimpangan seksual atau kecanduan seks semakin besar.

c. Pornografi dapat mendorong mereka melakukan tindakan seksual terhadap anak yang lebih muda, kecil dan lemah.

d. Tindakan pelecehan seksual yang terjadi di tempat yang dianggap kental nilai moralnya, seperti di lingkungan sekolah dan yang lainnya itu merupakan tindakan yang tidak sesuai dengan keadaan dan aturan yang berlaku di lingkungan tersebut. Pergaulan anak yang luas, otomatis anak juga memperoleh banyak masukan dari teman-temannya. 
e. Pendidikan Seks merupakan kebutuhan yang tidak bisa disampingkan atau ditutupi lagi, demi kepentingan masa depan anak.

2. Tanggapan guru tentang pornografi dan perilaku pelecehan seksual

1. Pronografi sering mengenalkan pada sensasi seksual sebelum waktunya. Padahal secara perkembangan, anak-anak belum siap menghadapinya. Pengetahuan tentang sensasi seksual ini dapat membingungkan dan memberi rangsangan berlebihan pada anak.

2. Hal-hal yang mengandung unsur porno baik itu berupa video maupun gambar dapat mempengaruhi sikap dan tingkah lakunya sehingga mendorong anak untuk melakukan pelecehan seksual.

3. Tindakan pelecehan yang dilakukan oleh anak menggambarkan bahwa moral dari pada anak tersebut tidak baik atau tidak pantas, sehingga perlu diberikan bimbingan atau pengajaran yang lebih serius tentang moral.

4. Konsep pembinaan dan pencegahan terhadap siswa yang membawa atau menyimpan gambar dan video porno melalui razia telah dilakukan oleh sekolah, dan memberikan sanksi terhadap siswa yang melanggar, namun belum efektif segala upaya yang dilakukan oleh sekolah.

5. Sikap pelecehan seksual yang dilakukan oleh anak usia sekolah merupaka sikap dan tindakan yang tidak sesuai dengan nilai serta norma yang berlaku di masyarakat. Dan sikap tersebut sudah melanggar hukum.

6. Pendidikan Seks yang diberikan secara seimbang antara pendekatan pengetahuan biologis dan pendekatan sosiologis bermanfaat pada anak, dan dapat membantu anak itu mengambil keputusan baik dalam kehidupannya.

\section{DAFTAR PUSTAKA}

Bakhtiar, Amsal, 2004. Filsafat Ilmu. Tantangan dan masa depan ilmu. Jakarta : PT Raja Grafindo Permai. Darajat, Zakiah, 1995. Remaja Harapan dan Tantangan. Bandung : PT Remaja Rosdakarya Offset.

Depdikbud, Kamus Besar Bahasa Indonesia (Jakarta : Balai Pustaka, 1990), 696

Dimas, Rasyid Muhammad, 2002. 20 Kesalahan dalam Mendidik Anak. Jakarata : Rabbani Press

Elizabeth, B. Hur lock, 1999. Psikologis Perkembangan. Jakarta : Erlangga 
http://meetabied.wordpress.com/2011/03/3

0/orang-tua-dan-pendidikan-moralbagi-anak

Kohlberg, L. \& Turiel, E. (1971). Moral pengembangan dan pendidikan moral. Dalam Lesser G., ed. Psikologi dan praktik pendidikan. Scott Foresman.

Kohlberg, Lawrence; T. Lickona, ed. (1976). "Tahap Moral dan moralization: Pendekatan kognitifperkembangan" Pengembangan Moral dan Perilaku: Teori, Riset dan Isu Sosial.. Holt, NY: Rinehart dan Winston.

Neng Djubaedah (Eds). Stop Pornografi Selamatkan Moral Bangsa (Jakarta:
Citra Pendidikan dan Pengurus Pusat Wanita Islam, 2004), 51

Ofsted 1994. Rohani, Moral, Pembangunan Sosial dan Budaya, Jakarta: Ofsted. Surya, M. 1990. Psikologi Perkembangan. Bandung : Publikasi Jurusan Psikologi

Syamsu, Yusuf, 2004. Psikologi Perkembangan Anak dan Remaja. Bandung: PT. Remaja Rosdakarya. Turiel, E. 983. Perkembangan Pengetahuan Sosial: Moralitas \& Convention. New York: Cambridge University Press. www.sexualrecovery.com “pornografi” (diakses 31 Maret 2011) 